\title{
INDUKSI MATURASI BELUT SAWAH (Monopterus albus) DENGAN HORMON HUMAN CHORIONIC GONADOTROPIN DAN ANTIDOPAMIN
}

\author{
Wiwin Kusuma Atmaja Putra, Agus Oman Sudrajat, dan Nur Bambang P.U. \\ Mayor IImu Akuakultur, Sekolah Pascasarjana, Institut Pertanian Bogor \\ J. Agatis, Kampus IPB Darmaga, Bogor \\ E-mail: wiwinbungo@yahoo.com
}

(Naskah diterima: 10 Mei 2013; disetujui publikasi: 28 Juni 2013)

\begin{abstract}
ABSTRAK
Penelitian maturasi belut sawah (Monopterus albus) dengan Hormone human Chorionic Gonadotropin dan antidopamin dilakukan di Kolam Percobaan Babakan, Institut Pertanian Bogor. Tujuan dari penelitian ini adalah untuk mengetahui pengaruh hormon hCG dan kombinasinya terhadap maturasi belut sawah. Penelitian ini dilakukan dengan metode ekperimental secara Rancangan Acak Lengkap (RAL) dengan perlakuan kontrol $(\mathrm{NaCl}$ ), hCG (dosis $20 \mathrm{lU} / \mathrm{kg}$ ), antidopamin (AD) (dosis 0,01 mg/kg), dan hCG+AD (dosis $20 \mathrm{IU}+0,01 \mathrm{mg} / \mathrm{kg}$ ) dengan tujuh ulangan individu. Data dianalisis secara deskriptif dan ANOVA. Parameter uji pada penelitian ini di antaranya adalah konsentrasi estradiol$17^{2}$, gonado somatik index (GSI), hepatosomatik index (HSI), histologi gonad, tingkat kematangan gonad, diameter telur, tingkat kebuntingan, dan kualitas air (oksigen terlarut (DO), $\mathrm{pH}$, amoniak, dan temperatur). Hasil terbaik pada akhir penelitian ini adalah perlakuan hCG+AD dengan nilai konsentrasi estradiol-172 (13,63-95,49 pg/ $\mathrm{mL})$, GSI (1,25\%), HSI (1 ,53\%), TKG (IV), diameter telur $(0,88 \mathrm{~mm})$, dan tingkat kebuntingan $(85,71 \%)$. Perlakuan kontrol dan antidopamin tidak berpengaruh dan hanya mampu mencapai tingkat kematangan gonad I. Hasil analisis parameter kulaitas air adalah berkisar DO (5,32-5,58 mg/L), amoniak (0,558-0,978 mg/L), pH (6,06-6,36), dan suhu $\left(27,80^{\circ} \mathrm{C}-27,94^{\circ} \mathrm{C}\right)$. Hasil ini menunjukkan bahwa hCG dapat menginduksi pematangan gonad belut sawah.
\end{abstract}

KATA KUNCI: hCG, antidopamin, maturasi, belut sawah

ABSTRACT: Induction hormone human chorionic gonadotropin and antidopamine of maturation rice field eel (Monopterus albus). By: Wiwin Kusuma Atmaja Putra, Agus Oman Sudrajat, and Nur Bambang P.U.

This research on induction maturasi of rice field eel (Monopterus albus) with Hormone human Chorionic Gonadotropin and antidopamine was conducted in Research Babakan Pond, Bogor Agricultural University. Intention of this research is know hormone hCG and combination influence to maturasi rice field eel. This research is conducted with method experimental in the complete random device (RAL) with treatment control $(\mathrm{NaCl}), h C G$ (dose $20 \mathrm{lU} / \mathrm{kg}$ ), antidopamin (AD) (dose $0.01 \mathrm{mg} / \mathrm{kg}$ ), and $\mathrm{hCG}+\mathrm{AD}$ (dose $20 \mathrm{IU}+0.01 \mathrm{mg} / \mathrm{kg}$ ) by seven individual restating. Data analysed descriptively and ANOVA. Parameter test at this research among other things is concentration estradiol$17^{2}$, gonado somatic index, hepatosomatic index, histologi gonad, mount maturity 
gonad, egg diameter, pregnant storey level, and the water quality ( $D O, p H$, temperature, and ammonia). The best results the end this research is treatment with hCG $+A D$ estradiol- $17^{2}$ concentration value (13.63-95.49 $\left.\mathrm{pg} / \mathrm{mL}\right), \mathrm{GSI}(1.25 \%)$, HSI (1.53\%), TKG (IV), egg diameter $(0.88 \mathrm{~mm})$, and pregnancy rate $(85.71 \%)$. Control treatment and antidopamin no effect and only able to reach the level of maturity of gonads $I$. Results the analysis of water quality parameters are range DO (5.32-5.58 $\mathrm{mg} / \mathrm{L}$ ), ammonia (0.558-0.978 $\mathrm{mg} / \mathrm{L}), \mathrm{pH}(6.06-6.36)$, and temperature $\left(27.80^{\circ} \mathrm{C}\right.$ $\left.27.94^{\circ} \mathrm{C}\right)$. These results indicate that $h C G$ can induce to rice field eel gonad maturation.

\section{KEYWORDS: hCG, antidopamine, maturation, rice field eel}

\section{PENDAHULUAN}

Belut adalah ikan air tawar yang bersifat hermaprodit protogini dan banyak hidup di persawahan, sungai dan laut. Reproduksi merupakan permasalah besar pada budidaya belut. Hormon yang mengontrol perkembangan gonad (maturasi) adalah hormon gonadotropin. Hormon gonadotropin terbagi dua jenis yaitu Folicle Stimulating Hormone (FSH) dan Luteinizing Hormone (LH). Hormon FSH merupakan gonadotropin yang berperan dalam proses vitellogenesis. Vitellogenesis adalah proses induksi dan sintesis vitellogenin di hati oleh hormon estradiol-1 $7^{2}$, serta penyerapan vitellogenin yang terbawa aliran darah ke dalam oosit (Tyler et al., 1991). Pada vitellogenesis sinyal lingkungan seperti hujan, temperatur, media diterima oleh sistem syaraf pusat dan diteruskan ke hipotalamus. Hipotalamus merespons dengan melepaskan Gonadotropin Releizing Hormone (GnRH) untuk bekerja pada kelenjar hipofisa. Selanjutnya, hipofisa akan melepas hormon FSH yang bekerja pada lapisan teka pada oosit sehingga terjadi sintesis testosteron pada lapisan teka. Setelah itu, testosteron masuk ke dalam lapisan granulosa dan terjadi proses pengubahan testosteron menjadi estradiol- $17^{2}$ oleh enzim aromatase. Hormon estradiol- $17^{2}$ akan merangsang hati untuk mensintesis vitellogenin yang merupakan bakal kuning telur. Vitellogenin akan dibawa oleh aliran darah menuju gonad dan secara selektif terjadi penyerapan oleh lapisan folikel oosit (Nagahama, 1983; Yaron, 1995; Blazquet et al., 1998). Akibat dari proses penyerapan vitellogenin adalah oosit akan tumbuh membesar sampai kemudian berhenti bila telah mencapai ukuran yang maksimum.

Sumber hormon FSH yang banyak digunakan dan didapat saat ini adalah PMSG (Pregnant Mare Serum Gonadotropin). Hormon
PMSG memiliki pengaruh FSH lebih kuat dibanding LH sehingga memberikan pengaruh kepada pemasakan folikel. Gonadotropin akan merangsang ovari untuk proses akhir pematangan telur pada gonad ikan (Bolamba et al., 1992). Hormon PMSG di bidang perikanan tidak dapat diperoleh dengan mudah, maka dicari alternatif hormon yang mudah diperoleh, salah satunya yaitu human Chorionic Gonadotropin (hCG). Hormon hCG adalah hormon gonadotropin yang disintesis oleh sel-sel sinsitio-trophobiast dari palsenta dan disekresikan dalam urin wanita hamil muda. hCG merupakan hormon glikoprotein yang mengandung $\mathrm{FSH}$ dengan bobot molekul 32.000 dan mengandung 236 asam amino sedangkan LH berbobot molekul 30.000 mempunyai 2 rantai asam amino, 1 subunit \pm yang dibentuk dari 96 asam amino dan 1 subunit ${ }^{2}$ terdiri atas 199 asam amino (Junquiera $\&$ Camerio dalam Muclis, 1997) dan mengandung karbohidrat sebesar 18\%-45\% (Combarnous, 1988). Aktivitas hormon hCG menyerupai LH dan sedikit menyerupai FSH. Hormon hCG merangsang peningkatan konsentrasi gonadotropin yang berfungsi pada proses vitellogenessis dan kematangan akhir (Aida et al., 1991). Antidopamin (AD) adalah bahan kimia yang berfungsi untuk memblok kinerja dopamin, sehingga hipothalamus dapat mensekresikan $\mathrm{GnRH}$ endogenous yang berupa FSHRH endogenous lebih banyak. Menurut Wang (2011), secara umum pada ikan, dopamin (DA) dapat menghambat proses rilis Luteinizing Hormone (LH) pada hipofisis. Permasalahan yang terjadi banyak anggapan bahwa hCG tidak dapat digunakan untuk maturasi gonad. Beberapa penelitian menunjukkan bahwa hCG dapat merangsang perkembangan gonad (rematurasi dan maturasi) secara injeksi kombinasi (PMSG+hCG) tetapi secara tunggal belum dilakukan. 
Aplikasi hormon hCG dan AD di antaranya terdapat pada penelitian pengaruh hCG terhadap produksi estradiol- $17^{2}$ pada ikan goldfish dengan dosis 10 IU dan 100 IU dapat merangsang produksi estradiol- $17^{2}$ pada tingkat kuning telur sekunder dan primer sebesar 0,5-1,5 ng/mL (Kagawa et al., 1984). Penelitian Fibriani (2010), penggunaan hormon PMSG+hCG pada ikan patin $20 \mathrm{IU}+10 \mathrm{IU} / \mathrm{kg}$ untuk proses rematurasi. Wibisono (2012) di mana penggunaan hormon PMSG+AD dengan dosis $15 \mathrm{IU}+0,01 \mathrm{mg} / \mathrm{kg}$ pada belut sawah memberikan pengaruh positif pada nilai GSI sebesar $2,36 \%$ dan memacu perkembangan gonad hingga TKG IV pada minggu ke-5.

Tujuan penelitian ini adalah mengetahui pengaruh hormon hCG dan kombinasinya terhadap maturasi belut sawah.

\section{BAHAN DAN METODE}

\section{Waktu dan Tempat}

Penelitian ini dilakukan pada bulan Oktober 2012 sampai dengan Juni 2013 di Kolam Percobaan Babakan, Institut Pertanian Bogor (IPB). Histologi gonad dilakukan di Laboratorium Kesehatan Ikan, Fakultas Perikanan dan Ilmu Kelautan, IPB. Analisis estradiol-172 menggunakan ELISA di Laboratorium Hormon, Fakultas Kedokteran Hewan, Institut Pertanian Bogor.

\section{Bahan dan Metode}

Belut sawah yang digunakan dalam penelitian ini dengan ukuran panjang $22 \pm 2 \mathrm{~cm}$ sebanyak 28 ekor, $\mathrm{NaCl}$, hormon hCG, antidopamin (AD), dan cacing Tubifex. Metode yang digunakan dalam penelitian ini adalah Rancangan Acak Lengkap (RAL) dengan empat perlakuan dan tujuh ulangan individu. Perlakuan yang diberikan adalah perlakuan kontrol ( $\mathrm{NaCl} 0,9 \%$ ), hCG (dosis $20 \mathrm{IU} / \mathrm{kg}$ ), antidopamin (AD) (dosis $0,01 \mathrm{mg} / \mathrm{kg}$ ), dan hCG+AD (dosis $20 \mathrm{IU}+0,01 \mathrm{mg} / \mathrm{kg}$ ).

Akuarium yang digunakan sebanyak empat buah dengan ukuran $79 \mathrm{~cm} \times 38 \mathrm{~cm} \times 40 \mathrm{~cm}$. Akuarium dibersihkan dengan menggunakan air bersih hingga bersih, lalu dijemur. Kemudian setelah kering diisi air setinggi $20 \mathrm{~cm}$, dan diberi larutan PK dengan dosis $2 \mathrm{mg} / \mathrm{L}$ dan didiamkan selama 1 hari. Setelah itu, air di dalam akuarium dibuang dan diisi air setinggi $7 \mathrm{~cm}$. Akuarium yang telah berisi air diberi aerasi, hiter, pelindung berupa serutan tali rafia dan paralon, dan diberi Oxcy Tetra Cyxlin (OTC) dengan dosis 0,5 g/volume air media penelitian. Pakan yang diberikan pada penelitian ini adalah cacing Tubifex. Pembiusan belut sawah dilakukan dengan obat bius dengan dosis $1 \mathrm{~mL} / 0,5 \mathrm{~L}$ air selama 3 menit, kemudian penyuntikkan dilakukan secara intramuscular dengan hormon yang telah ditentukan. Ikan yang telah disuntik dimasukkan pada wadah dengan aerasi yang kuat selama 6-10 menit untuk penyadaran. Belut yang telah sadar dimasukkan ke dalam akuarium penelitian.

Parameter uji yang diamati meliputi konsentrasi hormon estradiol-1 $17^{2}$ dalam darah (metode ELISA EIA 2693) yaitu semua reagen harus dibiarkan pada suhu kamar $18^{\circ} \mathrm{C}-25^{\circ} \mathrm{C}$ sebelum digunakan. Selanjutnya, dipersiapkan terlebih dahulu larutan standar dengan kosentrasi 12,5;25; 50; 100; 250; 1.000; 2.000 $\mathrm{pg} / \mathrm{mL}$; dan larutan QC (quality control). Adapun prosedur pengerjaan ELISA adalah sebagai berikut:

1. Dimasukkan ke dalam masing-masing sumur pelat (microplate) sebanyak 25 1/4L standar, sampel, dan QC (quality control)

2. Ditambahkan $200 \% \frac{1}{4}$ L konjugat enzim HRP (Estradiol Enzym Conjugate) ke dalam setiap sumur, kemudian dikocok perlahan selama kurang lebih 10 detik

3. Inkubasi pada suhu kamar selama 2 jam

4. Setelah diinkubasi, larutan pada pelat dibuang, dan dicuci dengan larutan pencuci (washing solution) dengan volume 300 1\%4 setiap sumur. Pencucian dilakukan sebanyak 4 kali menggunakan alat Microplate Strip Washer Elx50 ${ }^{T M}$. Setelah pencucian selesai, dikeringkan dengan cara dibanting secara perlahan pada kertas penyerap

5. Ditambahkan $100 \quad 1 / 4 \mathrm{~L}$ larutan larutan substrat (TBM Substrate) pada masingmasing sumur pelat

6. Sumur pelat diinkubasi selama 20 menit pada suhu ruang

7. Setelah inkubasi dengan larutan substrat, reaksi enzimatis dihentikan dengan menambahkan $50 \mathrm{1} / 4 \mathrm{~L}$ larutan penyetop (stop solution, $\mathrm{H}_{2} \mathrm{SO}_{4}$ 0,5 M) ke dalam setiap sumur pelat

8. Setelah itu, absorbans dibaca pada panjang gelombang $450 \mathrm{~nm}$ menggunakan ELISA reader (absorbance microplate reader Elx $808^{\mathrm{TM}}$ ) yang telah dilengkapi dengan program Gen 5 (BioTek ${ }^{\circledR}$ Instruments, Inc.). 
Pembacaan dilakukan tidak lebih dari 10 menit setelah penambahan larutan penyetop reaksi

Gonado Somatik indeks (GSI) yaitu dengan cara membandingkan bobot gonad dengan bobot badan, lalu dikalikan 100 dengan satuan persen (\%), Hepatosomatik Indeks (HSI) yaitu dengan cara membandingkan bobot hati dengan bobot badan, lalu dikalikan 100 dengan satuan persen (\%), histologi gonad (Gunarso, 1989), tingkat kematangan gonad (TKG) (Efendie, 2002; Bahri, 2000), tingkat kebuntingan yaitu dengan menjumlah belut sawah yang telah mengandung oogonia di dalam gonad, dan kualitas air (oksigen terlarut (DO), amoniak, pH, temperatur). Analisis data dilakukan secara deskriptif dan ANOVA.

\section{HASIL DAN BAHASAN}

\section{Konsentrasi Estradiol-1 $7^{2}$ dalam Darah Belut Sawah}

Hasil penelitian tentang konsentrasi hormon estradiol-1 $7^{2}$ dapat dilihat pada Gambar 1.

Hasil pada penelitian ini berdasarkan pola konsentrasi hormon estradiol-1 $7^{2}$ selama penelitian yang terbaik adalah pada perlakuan hCG $+A D$, dikarenakan ada tren meningkat yang teratur mulai minggu ke-2 yang menandakan induksi hCG+AD dapat merangsang peningkatan hormon estradiol$17^{2}$ dan proses vitellogenesis. Kualitas vitellogenesis dapat dilihat pada gambaran histologi gonad (Gambar 9) dan diameter telur (Gambar 6 dan 7). Hormon estradiol- $17^{2}$ akan meningkat sejalan dengan proses vitellogenesis dan akan menurun pada proses maturasi hingga final maturasi serta ovulasi (Nagahama, 1994). Hormon FSH dan $\mathrm{LH}$ yang terdapat dalam hCG (eksogenous) akan merangsang otak ( $\mathrm{Hy}$ pothalamus) untuk mensekresikan $\mathrm{GnRH}$ (FSHRH). Hormon GnRH akan bekerja di pituitari dan merangsang untuk mensintesis FSH. Hormon FSH akan masuk pada oosit (sel teka) dan merangsang sel teka mensintesis testosteron, kemudian testosteron akan masuk ke dalam sel granulosa. Pada sel granulosa terjadi pegubahan testosteron menjadi hormon estradiol- $17^{2}$ oleh enzim aromatase.

Hormon hCG +AD juga mengalami peningkatan pada minggu ke-4 hal ini berkaitan dengan komposisi FSH dan LH. Komposisi hCG sama dengan hormon pregnant mare serum gonadotropin (PMSG). Menurut Sakai et al. (1988), menyatakan bahwa ada peningkatan progresif dalam aktivitas aromatase, dinilai langsung oleh konversi

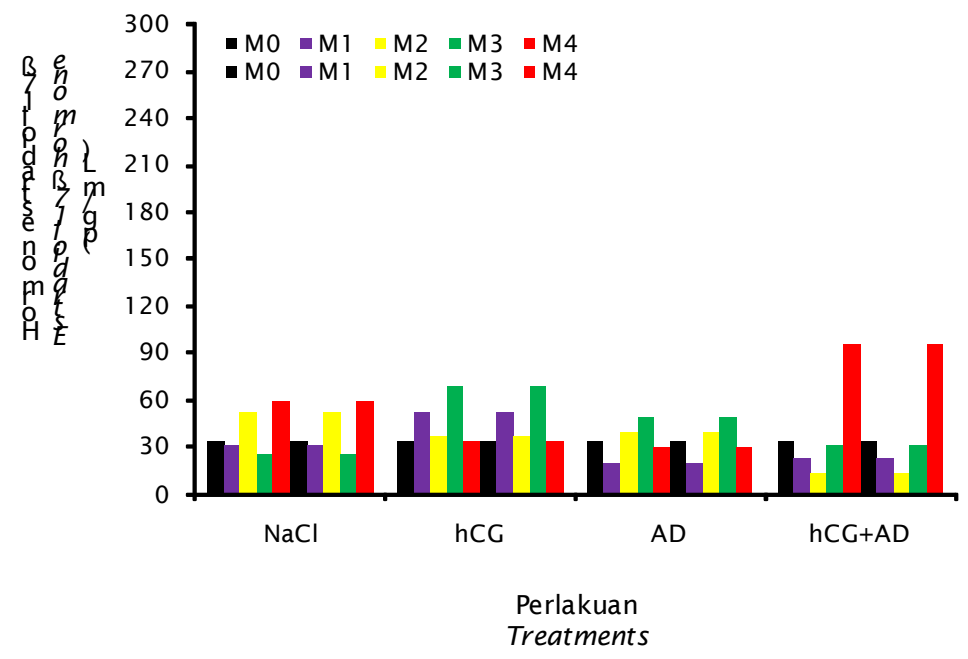

Keterangan:M0, M1, M2, M3, M4: minggu ke-0, ke-

1 , ke-2, ke-3, dan ke-4

Gambar 1. Konsentrasi hormon Estradiol-1 $7^{2}$ dalam darah belut sawah hasil induksi hormonal

Figure 1. Estradiol-1 $7^{2}$ hormone concentrations in the blood of the rice field eel hormonal induction 
testosteron eksogen untuk estradiol-1 $7^{2}$, di medaka (Oryzias latipes) folikel vitellogenik terisolasi antara 28-20 hari sebelum pemijahan. Penelitian ini dirancang untuk menentukan apakah kebuntingan dikarenakan PMSG (FSH) dan CAMP yang mampu menginduksi aktivitas aromatase dalam folikel vitellogenik awal terisolasi pada 32 jam sebelum pemijahan. Berdasarkan Wu (2011), bahwa pada belut gen yang lebih dulu timbul adalah gen LH sampai
300 hari setelah menetas dan FSH baru terlihat pada 300 hari setelah menetas.

\section{Hepatosomatik dan Gonado Somatik Indeks Belut Sawah}

Hepatosomatik index adalah nilai yang menggambarkan kondisi hati pada saaat proses perkembangan gonad yaitu berhubungan dengan produksi vitellogenin sebagai bakal

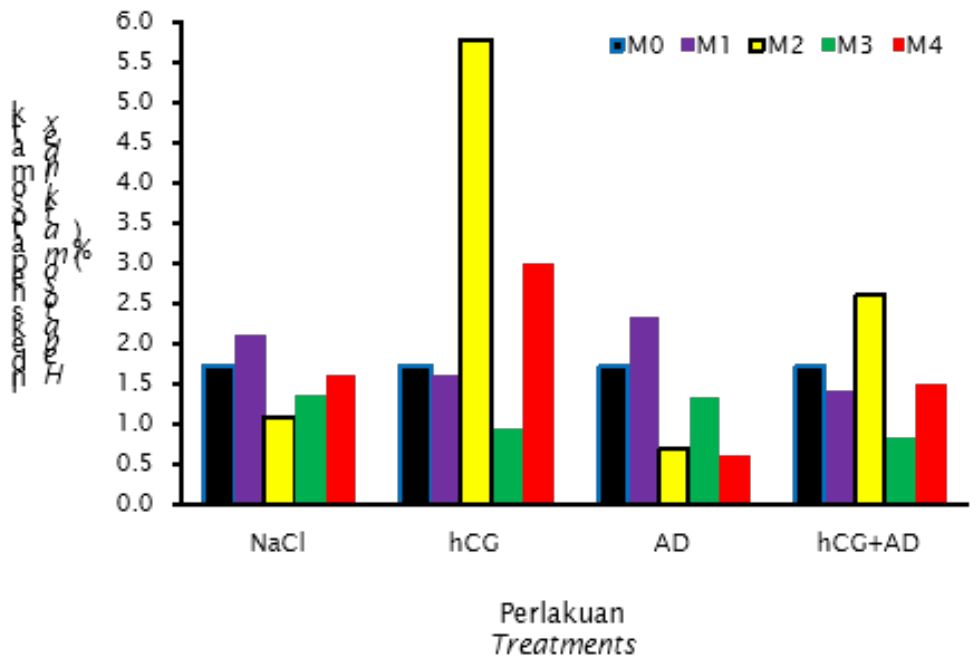

Keterangan:M0, M1, M2, M3, M4: minggu ke-0, ke-1, ke-2, ke-3, dan ke-4

Gambar 2. Indeks hepatosomatik belut sawah setiap minggu

Figure 2. Hepatosomatic index of rice field eel each week

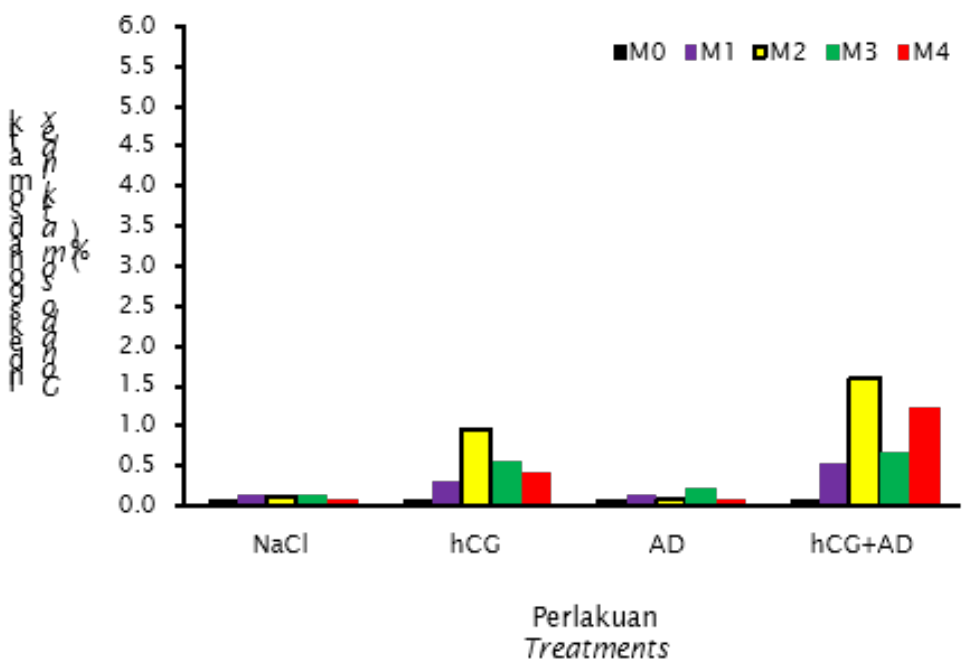

Keterangan:M0, M1, M2, M3, M4: minggu ke-0, ke-1, ke-2, ke-3, dan ke-4

Gambar 3. Indeks kematangan gonad belut sawah setiap minggu

Figure 3. Gonado somatic index of rice field eel each week 
kuning telur untuk perkembangan oosit dalam gonad yang dinyatakan dalam satuan persen (\%). Gonado somatik index merupakan nilai yang menunjukkan perkembangan dan pertumbuhan gonad ikan dibandingkan dengan bobot badan yaitu dinyatakan dalam satuan persen (\%).

Berdasarkan Gambar 2 dan 3, pada minggu ke-2 nilai HSI dan GSI pada perlakuan hormon hCG dan hCG +AD mengalami peningkatan sedangkan pada minggu ke-3 mengalami penurunan. Minggu ke-4 perlakuan hCG+AD mengalami peningkatan nilai HSI tetapi untuk GSI perlakuan hCG mengalami penurunan. Gambar 4 dan 5 secara ANOVA menunjukkan pengaruh yang nyata seluruh perlakuan terhadap nilai GSI dan HSI dibandingkan dengan kontrol $(F>0,05)$, di mana nilai tertinggi untuk HSI adalah perlakuan hormon hCG $(2,64 \%)$ dan GSI adalah perlakuan hormon hCG+AD (0,60\%).

Nilai HSI akan meningkat seiring dengan

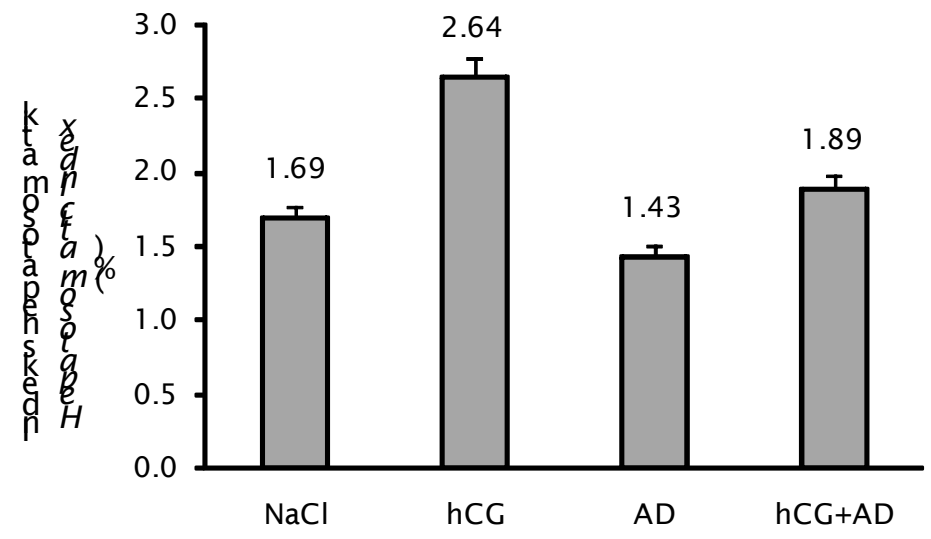

\section{Perlakuan \\ Treatments}

Gambar4. Indeks hepatosomatik belut sawah pada akhir penelitian

Figure 4. Hepatosomatic index of rice field eel by final of the research

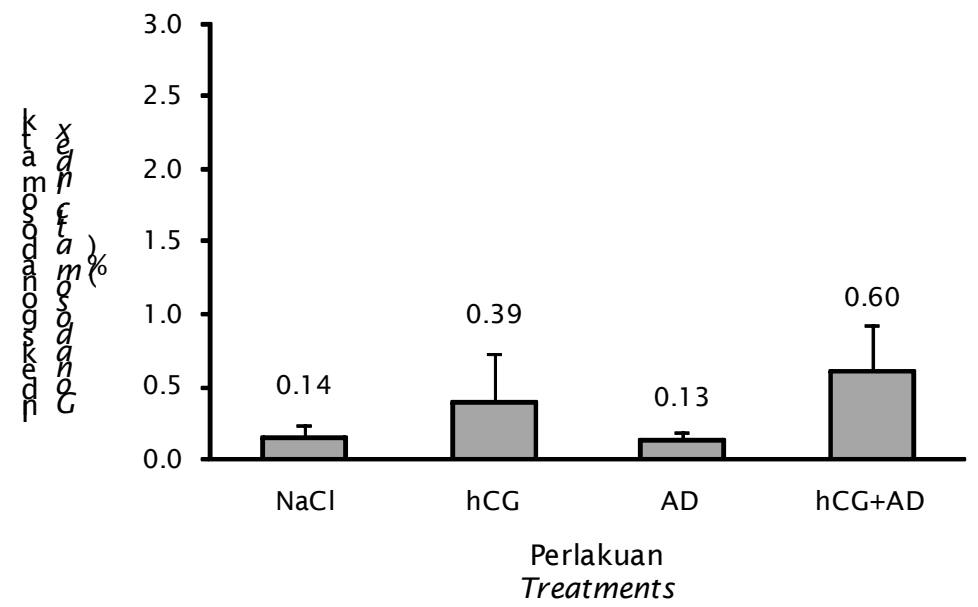

Gambar 5. Indeks gonadosomatik belut sawah pada akhir penelitian

Figure 5. Gonado somatic index of rice field eel by final of the research 
proses vitellogenesis dan akan lebih rendah dari CSI pada saat final maturasi. Hal ini disebabkan pada saat vitellogenesis hati akan berkembang dan mensintesis vitellogenin. Vitellogenin ini selanjutnya akan dibawa ke gonad untuk pembentukan kuning telur. Effendie (1997) menyatakan bahwa GSI akan semakin meningkat nilainya dan akan mencapai batas maksimum pada saat akan terjadi pemijahan. Semakin meningkat nilai GSI maka diameter telur dalam gonad akan semakin besar pula. Nilai CSI yang relatif kecil kemungkinan disebabkan ikan selain dalam proses reproduksi juga masih dalam proses pertumbuhan somatik, sehingga energi dari makanan yang masuk selain digunakan untuk reproduksi juga digunakan untuk pertumbuhan somatiknya. Granula kuning telur bertambah dalam jumlah dan ukuran sehingga menyebabkan volume oosit membesar pada saat proses vitellogenesis berlangsung (Nagahama, 1994). Effendi (1997) menyebutkan pertambahan gonad pada ikan betina secara umum berkisar antara 10\%-25\% dari bobot badan. Aktivitas vitellogenesis dapat menyebabkan nilai GSI dan HSI ikan meningkat (Cerdra et al., 1996).

\section{Diameter Telur Belut Sawah}

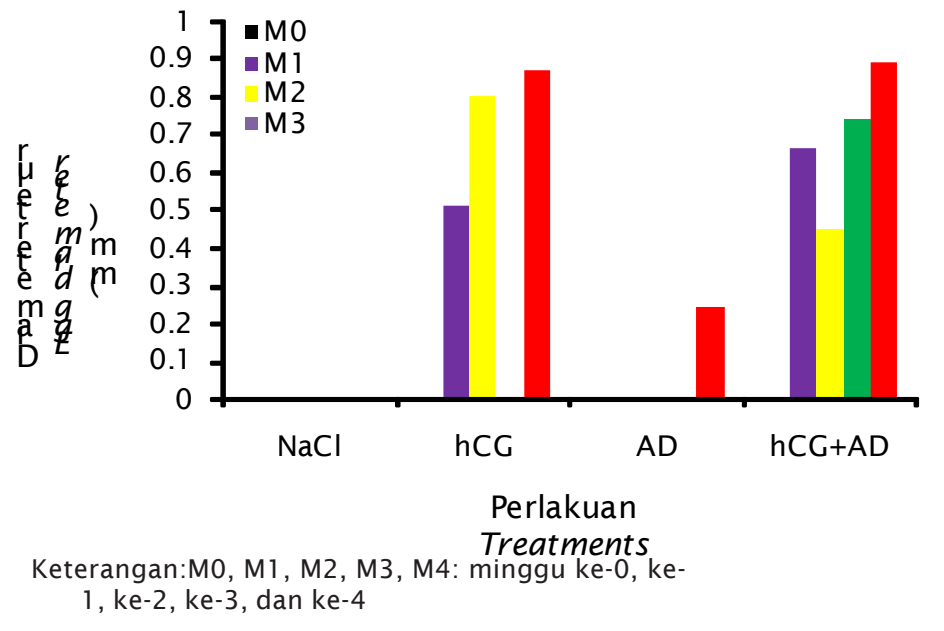

Gambar 6. Diameter telur belut sawah setiap minggu

Figure 6. Egg diameter of rice field eel each week
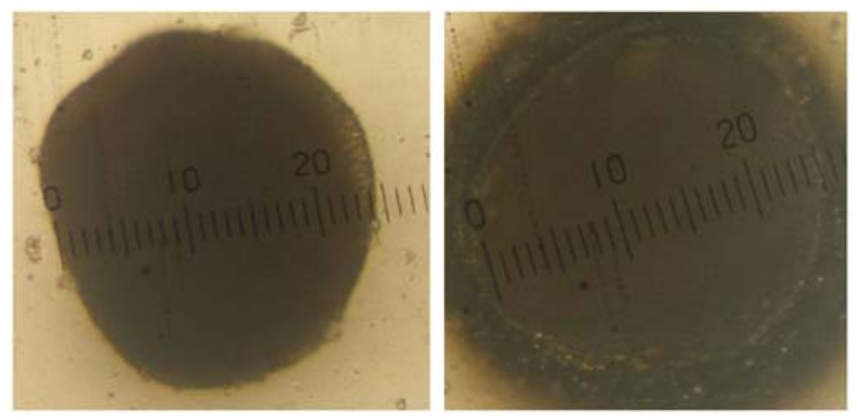

Gambar 7. Diameter telur belut sawah pada perlakuan (a) hCG dan (b) hCG+AD dengan pembesaran 40x

Figure 7. Egg diameter of rice field eel on treatment (a) hCG and (b) $h C G+A D$ with a $40 x$ magnification microscope 
Hasil dari pengukuran diameter telur belut setiap minggu dapat dilihat pada Gambar 6 .

Hasil terbaik dari penelitian ini adalah pada perlakuan $\mathrm{hCG}+\mathrm{AD}$ yaitu berkisar $0,4-0,8 \mathrm{~mm}$ (Gambar 7). Semakin meningkat nilai GSI maka diameter telur dalam gonad akan semakin besar pula. Hal ini disebabkan oleh pengaruh produksi vitellogenin oleh hati. Vitellogenin selanjutnya akan dilepaskan ke dalam sistem peredaran darah dan diserap secara selektif oleh oosit yang sedang berkembang untuk ditimbun menjadi bakal kuning telur. Hormon estradiol- $17^{2}$ akan merangsang hati untuk mensintesis vitellogenin (bakal kuning telur) yang nantinya berperan penting dalam perkembangan oosit hingga ukuran maksimal (final maturasi) (Nagahama, 1994).

\section{Morfologi dan Histologi Gonad Belut Sawah}

Gambaran morfologi dan histologi gonad belut sawah pada minggu ke-4 seperti Gambar 8 dan 9.

Hasil penelitian pada Gambar 8 dan 9 menunjukkan bawa terjadi perkembangan gonad hingga minggu ke-4. Perkembangan gonad yang baik adalah perlakuan $\mathrm{hCG}+\mathrm{AD}$ dan hCG, sedangkan $\mathrm{NaCl}$ dan AD hanya mencapai oogonia (bakal telur). Secara morfologi gonad memperkuat bahwa perlakuan terbaik adalah
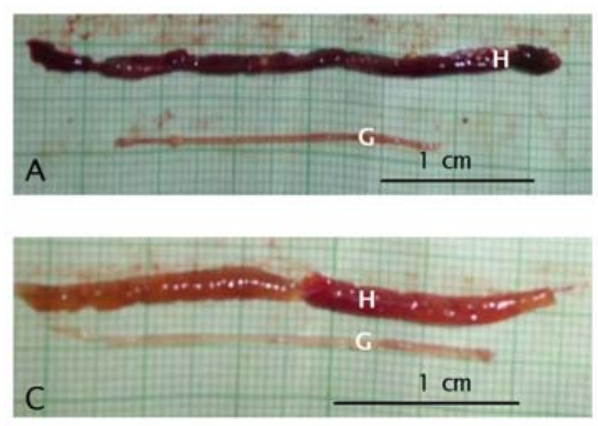

perlakuan hCG+AD dengan warna kekuningan.

\section{Tingkat Kematangan Gonad Belut Sawah}

Hasil dari pengamatan tingkat kematangan telur berdasarkan histologi gonad dapat dilihat pada Gambar1 0.

Berdasarkan Gambar 10, pada minggu ke-0 belut sawah masih pada tingkat kematangan gonad 0 . Hasil induksi hormonal pada belut sawah adalah pada minggu ke-1 dan ke-2 perlakuan hormon hCG dan hCH+AD meningkat tingkat kematangan gonadnya yaitu pada TKG II dan meningkat kembali pada minggu ke-3 yaitu TKG III dan pada minggu ke4 mencapai TKG IV. Perlakuan kontrol dan antidopamin pada minggu ke-4 di mana hanya mencapai TKG I.

Tingkat kematangan gonad berkorelasi dengan perkembangan gonad yaitu pergeseran inti telur (Nucleus) menuju pinggi dan telah melimpahnya butiran kuning telur pada gambaran histologi (Gambar 9) dan peningkatan diameter telur (Gambar 6) belut sawah. Menurut Bahri (2000), tingkat kematangan gonad IV paling banyak ditemukan pada kisaran ukuran panjang 21-30 cm. Menurut Wibisono (2012), di mana penggunaan hormon PMSG+AD dengan dosis $15 \mathrm{IU}+5 \mathrm{mg} /$ $\mathrm{L}$ pada belut sawah memberikan pengaruh positif pada nilai GSI sebesar 2,36\% dan
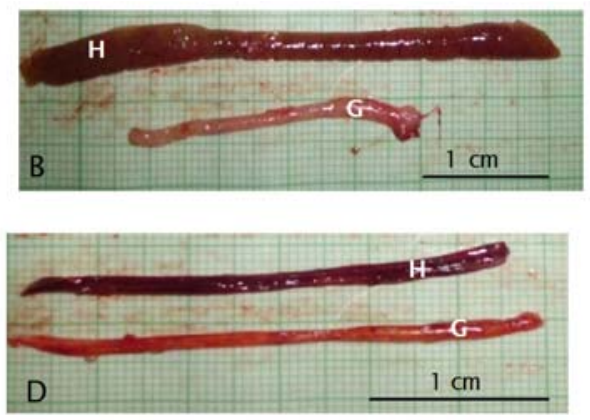

Gambar 8. Gonad dan hati belut sawah setiap perlakuan (A) NaCl, (B) hCG, (C) AD, dan (D) hCG+AD; H: hati, G: Gonad

Figure 8. Gonad and liver of rice field eel of every treatment (A) control, $(B) h C G,(C)$ $A D$, and $(D) h C G+A D ; H$ : Liver, G: Gonad 

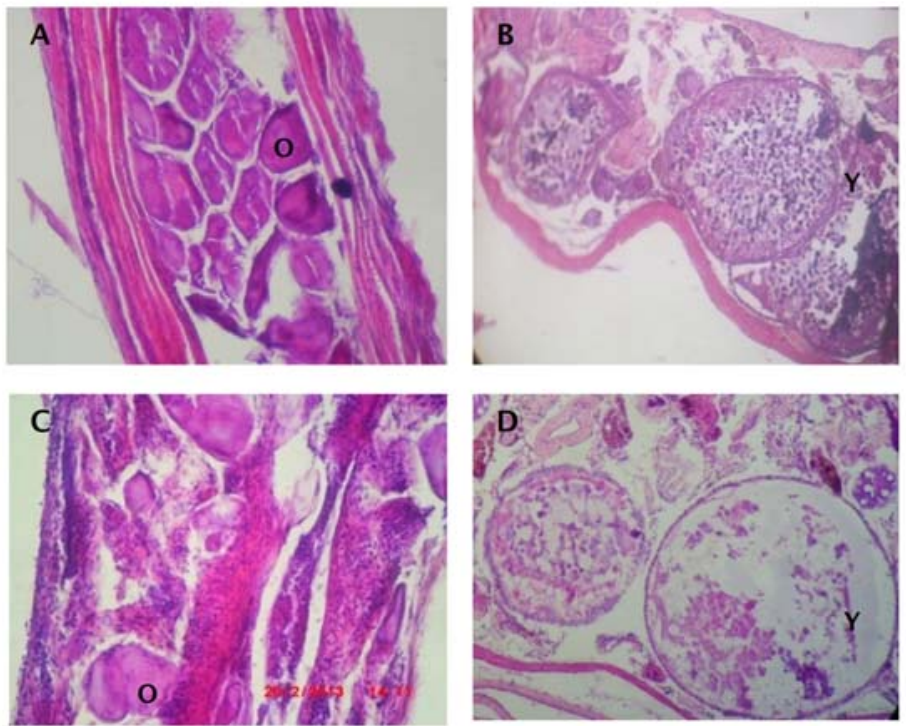

Gambar 9. Histologi gonad belut sawah pada perlakuan (A) $\mathrm{NaCl}$, (B) hCG, (C) antidopamin, (D) hCG+AD pada akhir penelitian, O: oogonia, Y: granula kuning telur

Figure 9. Rice field eel gonad histology on treatment (A) NaCl, (B) $h C G,(C)$ antidopamin, (D) $h C G+A D$ at the end of study, Letter O: Oogonia, Y: yolk granule

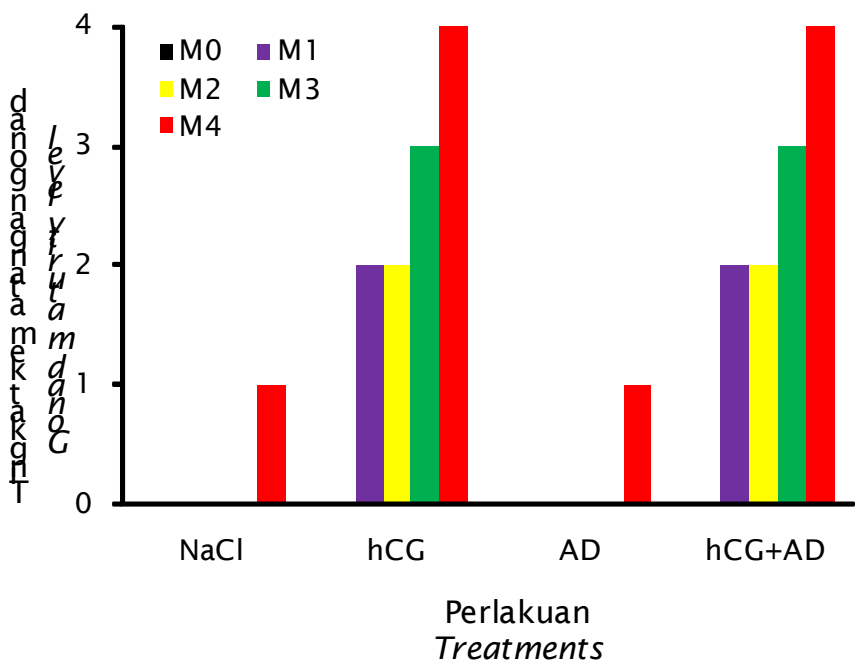

Keterangan:M0, M1, M2, M3, M4: minggu ke-0, ke-

1, ke-2, ke-3, dan ke-4

Gambar 10. Tingkat Kematangan Gonad belut sawah setiap minggu

Figure 10. Gonad maturity level of rice fields eel every week 


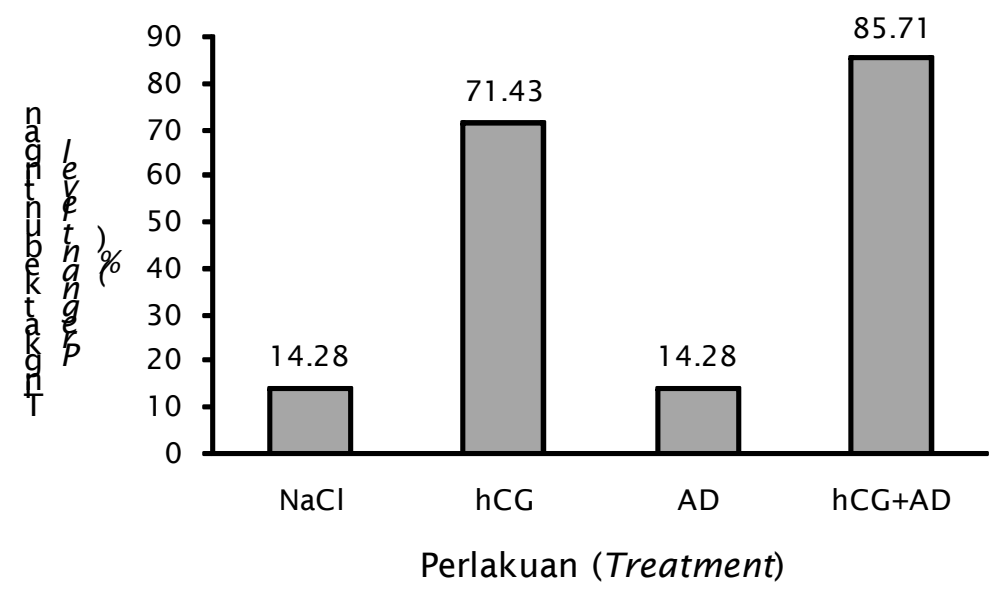

Gambar 11. Tingkat kebuntingan belut sawah selama penelitian Figure 11. Pregnancy rate during of rice fields eel in the research

memacu perkembangan gonad hingga TKG IV pada minggu ke-5.

\section{Tingkat Kebuntingan Belut Sawah}

Hasil dari parameter uji tingkat kebuntingan belut sawah hasil induksi hormonal dapat dilihat pada Gambar 11 .

Berdasarkan Gambar 11, tingkat kebuntingan belut sawah yang paling tinggi adalah pada perlakuan hCG+AD sebesar
$85,71 \%$; sedangkan perlakuan kontrol dan antidopamin sebesar $14,28 \%$ dan perlakuan hormon hCG sebesar 71,43\%. Perbedaan kualitas dari perlakuan hormon terhadap belut dapat di lihat pada Tabel 1. Hasil tingkat kebuntingan belut membuktikan perlakuan hCG+AD lebih baik dibandingkan perlakuan yang lainnya. Tabel 1 memberikan gambaran banyaknya belut sawah pada setiap tingkat kematangan gonad. Penelitian Wibisono (2012) menyatakan bahwa tingkat kebuntingan belut

Tabel 1. Jumlah belut sawah pada setiap tingkat kematangan gonad selama penelitian

Table 1. Rice fields eel in every gonad during maturity levels the research

\begin{tabular}{|c|c|c|c|c|c|c|}
\hline \multirow{2}{*}{$\begin{array}{l}\text { Perlakuan } \\
\text { Treatments }\end{array}$} & \multicolumn{5}{|c|}{$\begin{array}{l}\text { Tingkat kematangan gonad (ekor) } \\
\text { Gonadal during maturity (ind.) }\end{array}$} & \multirow{2}{*}{$\begin{array}{l}\text { Jumlah belut yang } \\
\text { bunting (ekor) } \\
\text { Number of pregnant of } \\
\text { rice field eel (ind.) }\end{array}$} \\
\hline & 0 & I & II & III & IV & \\
\hline $\begin{array}{l}\text { Kontrol } \\
\text { Control }\end{array}$ & 6 & 1 & - & - & - & 1 \\
\hline $\mathrm{hCG}$ & 2 & 1 & 1 & 2 & 1 & 5 \\
\hline $\mathrm{AD}$ & 6 & 1 & - & - & - & 1 \\
\hline$h C G+A D$ & 1 & 1 & 2 & 1 & 2 & 6 \\
\hline
\end{tabular}

Keterangan:hCG: human Chorionic Gonadotropin; AD: Antidopamin; TKG: tingkat kematangan gonad (gonad maturity level) 
Tabel 2. Kualitas air media penelitian belut sawah

Table 2. Water quality media the research rice field eel

\begin{tabular}{|c|c|c|c|c|}
\hline \multirow{2}{*}{$\begin{array}{l}\text { Perlakuan - } \\
\text { Treatments }\end{array}$} & \multicolumn{4}{|c|}{$\begin{array}{c}\text { Parameter kualitas air } \\
\text { Parameter of water quality }\end{array}$} \\
\hline & $\begin{array}{c}\text { Oksigen terlarut } \\
\text { Dissolved oxygen } \\
\qquad(\mathrm{mg} / \mathrm{L})\end{array}$ & $\begin{array}{c}\text { Amoniak } \\
\text { Ammonia } \\
\text { ( } \mathrm{mg} / \mathrm{L})\end{array}$ & $\mathrm{pH}$ & $\begin{array}{c}\text { Suhu } \\
\text { Temperat ure } \\
\left({ }^{\circ} \mathrm{C}\right)\end{array}$ \\
\hline $\begin{array}{l}\text { Kontrol } \\
\text { Control }\end{array}$ & 5.44 & 0.558 & 6.25 & 27.94 \\
\hline hCG & 5.38 & 0.978 & 6.28 & 27.92 \\
\hline $\mathrm{AD}$ & 5.32 & 0.73 & 6.06 & 27.8 \\
\hline$h C G+A D$ & 5.58 & 0.735 & 6.36 & 27.94 \\
\hline
\end{tabular}

Keterangan:hCG: human Chorionic Gonadotropin; AD: Antidopamin; TKG: tingkat kematangan gonad (gonad maturity level)

sawah dengan induksi hormon PMSG+AD dengan dosis $15 \mathrm{IU}+5 \mathrm{mg} / \mathrm{L} / \mathrm{kg}$ adalah sebesar $80 \%$.

\section{Kualitas Air Media Penelitian}

Hasil analisis kualitas air ini masih dalam kisaran toleransi kehidupan belut sawah. Menurut laporan kerja praktek Putra (2009), bahwa $\mathrm{pH}$ air pada habitat alami belut sawah adalah 6. Ellis dalam Boyd (1990) menyatakan bahwa $\mathrm{pH}$ yang sesuai untuk kehidupan ikan berkisar antara 6,5-9,0. Menurut Putra (2010), temperatur air media penelitian belut sawah adalah $24^{\circ} \mathrm{C}-28^{\circ} \mathrm{C}$ dan belut sawah masih dapat mempertahankan kelangsungan hidupnya. Iklim yang baik untuk belut adalah iklim tropis dengan kisaran temperatur $25^{\circ} \mathrm{C}-28^{\circ} \mathrm{C}$ (Yamamoto \& Tagawa, 2000). Menurut Putra (2010), kandungan oksigen terlarut dalam air media penelitian adalah 2,36-0,6 mg/L (pakan cacing Tubifex); 2,36-0,32 mg/L (pakan jangkrik); 4,2-0,61 mg/L (pakan ulat hongkong); dan 1,96-0,61 mg/L (pakan pelet). Kandungan oksigen terlarut dalam air yang ideal untuk tumbuh dan berkembangnya ikan adalah 5-6 $\mathrm{mg} / \mathrm{L}$. Menurut Putra (2010), kandungan amonia dalam media penelitian adalah 2,99-6,88 mg/L (pakan cacing Tubifex); 0,99-4,77 mg/L (pakan jangkrik); 0,51-3,63 mg/L (pakan ulat hongkong); dan 0,79-2,16 mg/L (pakan pelet). Boyd (1990) menyatakan bahwa kadar amonia yang baik bagi kehidupan ikan dan organisme perairan lainnya adalah kurang dari $1 \mathrm{mg} / \mathrm{L}$.

\section{KESIMPULAN DAN SARAN}

Induksi maturasi dengan hormon hCG+AD (dosis $20 \mathrm{IU}+0,01 \mathrm{mg} / \mathrm{kg}$ bobot badan) dapat menginduksi proses maturasi gonad belut sawah selama 4 minggu.

Manipulasi reproduksi secara hormonal pada belut sawah ukuran lebih besar dan penelitian efektivitas dosis hCG dapat dilakukan.

\section{DAFTAR ACUAN}

Aida, K., Kobayashi, M., \& Kaneko, T. 1991. Endokrinologi (dalam Bahasa Jepang) dalam Hazawa, M. \& Hanyu, I (Eds.). Fisiologi Ikan. Koseisha Koseikaku. Tokyo, p. 167-241.

Bahri, F. 2000. Studi mengenai aspek biologi ikan belut (Monopterus albus) di Kecamatan Parung Kabupaten Bogor, Jawa Barat. Skipsi. Fakultas Perikanan dan IImu Kelautan. IPB, Bogor.

Blazquet, M., Bosma, P.T., Fraser, E.J., van Look, K.J.W., \& Trdeu, V.L. 1998. Fish as model for the neuroendocrine regulation of reproduction and growth. Com. Biochem. Physiol, Part C., 199: 345-364.

Bolamba, D., Matton, P., Estrada, R., \& Dufour, J.J. 1992. Effect of pregnant mare's serum gonadotropin on follicular population and ovulasi rates in prepubertal gilts with two morphologically different ovarium types. J. Anim. Sci., 70: 1,916-1,992.

Boyd, C.E. 1990. Water quality management in pond fish. Research and Development Series No. 22. International for Aquaculture. Agriculture Experiment Station. Auburn Alabama, 
Cerda,J., Calman, B.G., Lefleur, G.J.Jr., \& Limesand, S. 1996. Patten of vitellogenesis and ovarian folicular cycle of Fundulus heteroclitus. Gen. Comp. Endo., 103: 24-35.

Effendie, M.I. 1997. Biologi perikanan. Yayasan Pustaka Nusantara, Bogor.

Effendie, M.I. 2002. Biologi perikanan. Yayasan Pustaka Nusantara. Yogyakarta, hlm. 5.

Fibriana, C. 2010. Rekayasa rematurasi ikan patin siam (Pangasianodon hypophthalmus) dengan kombinasi penyuntikan hormon PMSG dan hCG serta penambahan vitamin mix $100 \mathrm{mg} / \mathrm{kg}$ Pakan. Skripsi. IPB, Bogor.

Gunarso, W. 1989. Mikroteknik. PAU, Ilmu Hayat. Institut Pertanian Bogor. Bogor.

Alit, I G.K. 2009. Pengaruh padat penebaran terhadap pertambahan berat dan panjang badan belut sawah (Monopterus albus). Jurusan Biologi Fakultas MIPA. Universitas Udayana. Kampus Bukit Jimbaran, Bali.

Hoars, W.S., Randall, D.J., \& Donaldson, E.M. 1993. Fish physiology. Volume IX, Reproduction. Part B. Behaviour and Fertility Control. Academic press Inc, London.

McMillan, D.B. 2007. Fish histology. Female Reproductive Systems Department of Biology. The University of Western Ontario London, Ontario Canada. p. 603.

Mehlmann, L.M. 2005. Stops and starts in mammalian oocytes: recent advances in understanding the regulation of meiotic arrest and oocyte maturation. Department of Cell Biology, University of Connecticut Health Center, Farmington Ave. Farmington, USA, p. 263.

Nagahama, Y. 1983. The functional morphology of teleost gonads. In Hoar, W.S., Randall, D.J., \& Donaldson, E.M. (Eds.). Academic Press, In. Fish Physiology, IXB: 223275.

Nagahama, Y. 1994. Review, endocrine regulation of gametogenesis in fish. Laboratory of Reproductive Biology, National Institute for Basic Biology, Okazaki, Japan, Int. J.O., Biol., 38: 217-229.

Nagahama, Y. 1995. Regulation of oocite growth and maturation in fish. Dev. Biol., 30: 103-104.

Putra, W.K.A. 2009. Prospek budidaya belut di Desa Mertasari dan Desa Kalipelus Kecamatan Purwanegara Kabupaten Banjarnegara. Laporan Kerja Praktek, Unsoed, Purwokerto.
Putra, W.K.A. 2010. Laju pertumbuhan dan konversi pakan belut sawah (Monopterus albus) dengan pemberian berbagai pakan hewani dalam media air. Skripsi. Jurusan Perikanan dan Kelautan. UNSOED, Purwokerto.

Ridwan, A. \& Tang, U.M. 2002. Fisiologi Hewan Air. Universitas Riau Press. Riau, hlm. 213: 172-195.

Ridwan, A., Ernawati, Y., \& Wahyudi, S. 2003. Studi bio-ekologi Belut Sawah (Monopterus albus) pada berbagai ketinggian tempat di Kabupaten Subang, Jawa Barat. Fakultas Perikanan dan Ilmu Kelautan, IPB, Bogor.

Taufik, A.H. 2010. Pertumbuhan belut (Monopterus albus Zuieuw) yang dipelihara dalam boks plastik pada skala laboratorium dengan kombinasi pakan berbeda. Skripsi. Jurusan Perikanan dan Kelautan. Universitas Soedirman, Purwokerto.

Tyler, C.R., Sumpter, J.P., \& Cambell, P.M. 1991. Uptake of vitellogenesis into oocyte during early vitellogenic in the rainbouw trout, Oncorincus mykiss. W. J. Fish. Biol., 38: 681689.

Wang, X., Taiqiang, Z., He, W., \& Hong, Z. 2011. Jourrnal general and comparative endocrinology: regulation of dopamine D2 receptor expression in grass carp pituitary cells. School of Life Science and Technology, University of Electronic Science and Technology of China, Chengdu 610054, People's Republic of China, 173: 48-55.

Wibisona, R.W. 2012. Artificial maturation pada ikan belut sawah Monopterus albus melalui penggunaan kombinasi hormon Pregnant Mare Serum Gonadotropin Dosis 5, 10, dan 15 IU dengan antidopamin 5 ppm. Skripsi. Fakultas Perikanan dan IImu Kelautan. IPB, Bogor.

Wu, Y., He, Z., Zhang L., Jiang, H., \& Zhang, W. 2011 . Ontogeny of immunoreactive Lh and Fsh cells in relation to early ovarian differentiation and development in protogynous hermaphroditic ricefield eel (Monopterus albus). Sun Yat-Sen University, China.

Yaron, Z. 1995. Endocrine control of gametogenesis and spawning induction in the carp. Aquaculture, 129: 49-73.

Yamamoto, M.N. \& Tagawa, A.W. 2000. Hawai Native and Exotic Freshwater Animals. Mutual Publishing, Honolulu, Hawaii. p. 200.

Zhou, W.Z., Zhang, L., Gao, H.L., \& Li, H.T. 2007. Pilot studies on half-manual breeding of ricefield eels in shallow water without soil. Chinese Electronic Periodical Services. (abstract). http://www.ceps.com/ec/ ecjnlarticleView. Diakses tanggal 29 Januari 2009. 